the department of geography at the Rhode Island Normal School, Providence, R. I.

Aт University College, Reading, Mr. S. B. McLaren, assistant lecturer in mathematics at Birmingham University, has been appointed professor of mathematics, and Mr. R. C. McLean lecturer in botany.

\section{DISCUSSION AND CORRESPONDENCE}

THE NAME OF THE SHEEP MEASLE TAPEWORM

COBBoLd in 1866 described a cysticercus from the muscles of sheep in England and named it Cysticercus ovis. The same species was later described by Maddox (1873) under the name of Cysticercus ovipariens. Other authors have considered the parasite to be either Cysticercus cellulos $\infty$, the intermediate stage of Tonia solium, in an unusual host, or Cysticercus tenuicollis, the intermediate stage of Trenia marginata or hydatigena, in an unusual location (muscles instead of serous membranes). Recent investigations by the present writer have proved that the parasite in question is neither $C$. cellulose nor $C$. tenuicollis but the intermediate stage of a distinct species of $\operatorname{dog}$ tapeworm. The correct name of this tapeworm would, therefore, seem to be Trenia ovis (Cobbold, 1866). $\quad$ B. H. Ransom

BuREaU of ANIMAL INDUStry, Washington, D. C.

NOTE ON THE ORIENTATION OF BOMBILIUS TO LIGHT

WHILE on the hills east of Berkeley, Cal., I observed, among numerous insects visiting the flowers of certain shrubs, that there were several flies which kept hovering for a considerable time in almost exactly the same position. The flies proved to belong to a species of Bombilius. The instinct of hovering is not rare among the Diptera, especially the Syrphidæ, but what especially attracted attention was the accurate orientation of the hovering insects to the rays of light. In all the numerous cases observed the flies had their backs turned toward the sun, and in all cases the hovering occurred in the direct sunlight. Whenever a shadow was thrown upon a hovering fly it immediately darted elsewhere.
Occasionally the flies alighted on the ground, when they rested with the back exposed to the sun as before. When a shadow was thrown on them they would soon fly to a sunnier spot. In a few cases I caused them to orient obliquely to the sun's rays by slowly moving an object so that its shadow was thrown on only half the body of the insect; the body would then be turned so as to face more nearly the center of the shaded region. In basking in sunny spots and in orienting negatively to the rays of light the behavior of Bombilius resembles that of the mourning-cloak and other butterflies described by $\mathrm{Radl}$ and Parker. Like the mourning-cloak, Bombilius under ordinary circumstances is positively phototactic. It will fly or walk toward the light as so many other Diptera do, but when resting on the ground in the sunshine or hovering in the air it assumes a negative orientation. It is of interest to find such striking similarities of behavior in two distantly related orders of insects.

When resting on the ground or hovering, Bombilius often darts quickly at passing insects. It is not very discriminating as to the objects of its approach and was several times seen to follow after honey-bees and twice after yellow-jackets. When the fly meets a member of its own species the two often spin around in a rapid whirl, but when a mistake is made the pursuit is immediately abandoned. I have caused Bombilius as well as other species of hovering flies to dart after small pebbles that were tossed in the air. This behavior is probably associated with the instinct of mating, since it occurs in nonpredatory as well as predatory species.

\section{S. J. Holmes}

\section{SCIENTIFIC BOOKS}

Handwörterbuch der Naturwissenschaften. Herausgegeben von E. Konschelt, Zoologie; G. LINck, Mineralogie u. Geologie; F. OLTmanns, Botanik; K. Schaum, Chemie; H. Th. Simon, Physit; M. Verworn, Physiologie, und E. Teichmann, Hauptredaktion. Jena, Verlag von Gustav Fischer. 1912. 
In order to review a book it is at least extremely desirable to have read it. Reading the encyclopedia is not "jedermann's Sache" and, unlike Agamemnon in the story of the Peterkin family, the present writer can not pretend to have done it, but he has at least carefully examined each of the forty-six "Lieferungen" of 160 pages each, which have so far appeared of this admirable work, and has perused with care many of the articles on which he is competent to have an opinion. The first thing that must certainly strike the scientific man on opening this work is the feeling of regret that it is impossible to produce such a work in America, and, secondly, that, if it were, no publisher could be found to undertake it, for the, to him, very convincing reason that he would not be able to make any money out of it. Germany is preeminently the country of encyclopedias, and if one can judge of German greatness from the thoroughness with which they go about the manufacture of these aids to knowledge he can but wonder why the Germans have not already conquered the world. To be sure France is the home of what must always be known as the encyclopedia, to say nothing of Larousse and similar undertakings, and England is the home of eleven editions of the Britannica, to which in these latter days American methods of scientific management and booming have been added as well as British and American learning; but when we look at the "Encyclopaedie der mathemetischen Wissenschaften," which has been appearing now for thirteen years, and is not yet complete, and which has compelled the French to publish a French edition based with great fidelity upon it, we must admit the impossibility of competition in this line.

The present work is, so far as known to the reviewer, the first attempt made, even in Germany, to produce an encyclopedia of all the natural sciences, and must put all scientists, as well as all liberally educated laymen who can read German (and the contrary is a negation of terms) under great obligations to the house of Fischer, so well known among the great publishing houses of scientific works. It seems rather a pity that mathematics could not be included, because, although not a natural science, it is, if not the greatest of the sciences, at least the common tool and competent servant of all. Of course mathematics is taken care of in the great work named above, but that is no reason that it should not have been treated in a briefer and less technical way in a work of the scope of the present one, and its exclusion results in the inclusion of articles largely of a mathematical nature, such as the one on Flüssigkeitsbewegung, which appear in the mathematical encyclopedia by the nature of things, and also appear here as physical articles. In this connection the reviewer may perhaps be permitted to animadvert on the absurd classification of mathematics with philosophy, say in the group system at Harvard, which removes it from its closest friends and relatives, physics, astronomy and chemistry, and puts it along with an almost total stranger, and calls it to the attention of people most of whom are totally unable to use it. So much for logic, so little for common sense.

What most impresses the reader of the work under consideration is the great competence of the writers of the articles, and their absolute up-to-dateness. To be sure, some of the authors are decidedly young, but their articles are none the less good, and we must bear in mind the great number in Germany of brilliant minds among very young men, at least in physics. As an example of contemporaneousness we find in the extremely interesting article on Flüssigkeitsbewegung by Professor Prandtl, of Göttingen, mention of the most recent researches on fluid resistance, illustrated by a beautiful photograph of vortexmotion, involving work done only last year, while the famous principle of relativity, which was invented only in 1905, is treated in several articles, although not under a special heading. The articles on radioactivity and other radiations, those on Luftfahrt and Luftpumpe are further examples, the latter giving an excellent description of Gaede's new molecular air pump, a characteristically German invention, 
which, like the America in the yacht race, is first, with no second.

This encyclopedia will fortunately not fill a five-foot shelf, but if we may judge from the present 46 parts, reaching Skelett, may go about to 60 and fill a little over two feet. According to German custom, it is issued unbound, and the parts do not appear in strict alphabetical order, which makes a slight diffculty in knowing at the present time exactly what it will contain. Nevertheless, the paging will be perfectly consecutive, and the piecemeal method of appearance has the advantage of permitting the articles to have the greatest possible freshness, and does not lead to the errors that sometimes crept into the "Britannica" from the immensity of the task of printing. The only possible comparison of the present work is with the "Britannica," which, although of general scope, contains scientific articles which are of the same general caliber as these. In both cases the articles are not popular, and are written by thoroughly competent writers, but at the same time they are interestingly written, and so clear as to be understood by the layman desiring to obtain exact knowledge. The present encyclopedia is issued at 2.50 Marks per part, so that if there shall be sixty, the cost of the whole will be less than forty dollars, exclusive of binding, a price that will make its ownership possible to many a scientific man to whom the "Britannica" at one hundred and twenty-five dollars would be an impossibility. The form of the page is also much more convenient than that of the "Britannica," and the volumes are less unwieldy. The print is as good, if not better, although decidedly different, the type being blacker and somewhat clearer, although not leaded, so that it is not easy to say which is the easier to read. The printing is, however, certainly as good, and the illustrations, at least in the opinion of the reviewer, are decidedly better, some of the biological illustrations being beautiful to look at, and even the physical ones being remarkably clear. The reviewer admits with pain that many of the cuts in the "Britannica" have to him a decidedly cheap look, which is never the case in the German work. These are photoengravings of a high quality of workmanship, and are used in great profusion. For instance, in the article Ei und Eibildung we find a thirty-three-page article profusely illustrated with beautiful and instructive cuts, while in the article Egg in the "Britannica" we find an article of three and a half pages, without a single picture. Undoubtedly the matter of the article is found somewhere else, but as a matter of fact the article on Embryology is similarly devoid of illustrations. Whether this is due to the smaller expense of printing illustrations in Germany we do not know, but the presence of the illustrations is a very desirable feature.

It is obviously impossible for any individual scientist to comment on all the sciences, so that the reviewer will confine himself to singling out a few articles on subjects with which he is familiar. The article on Elektrooptik is by Professor Voigt, of Göttingen, the chief authority on the subject, and the article on Lichtbogenentladung, a forty-page article on a new subject, by Professor Simon, of Göttingen, is a mine of information on that subject, with very attractive figures, reproductions of oscillograms by the author. All the electrical articles are well handled; we will mention only that on Elektrodynamik, by $\mathrm{H}$. Scholl, which includes the treatment of all the theories from the classical ones down to the theory of relativity, in compact and clear statement, and that on Elektrische Masssysteme, by F. Emde, in which, beside a very clear treatment of the subject, we find a very ingenious graphical treatment by a diagram showing not only the dimensions, but also the relative magnitudes of the most important dynamical units. For the sake of comparison we will consider the articles on Elasticity in the "Britannica" and the present work in some detail. In the "Britannica" we have a nineteen-page article by Professor Love, of Oxford, the author of the leading treatise on the subject in any language, in which the leading equations of the theory are stated, with the chief practical results, without any great mathematical detail. In the German work we have an article of twenty-seven pages 
by Dr. Th. v. Kármán, who, although a very young man, has no need to apologize for his article, which, although containing fewer formulæ, is written with great clearness and has even better cuts than the English article. To be sure Dr. Kármán had the advantage of reading Professor Love's article as well as his great treatise, but the article is decidedly independent, and concludes with an excellent treatment of elastic hysteresis or Nachwirkung, which is becoming more and more important, and which we do not find mentioned in Professor Love's article. Very likely this is also due to the more recent appearance of the German work. For the biologist we will mention the fifty-three-page article on Descendenztheorie, profusely illustrated, as compared with the "Britannica" article on Evolution, of fifteen pages, without illustrations.

A feature of the present work that is of great importance is found in the biographical sketches, which, although very short, are decidedly helpful. We have looked in vain for the name of Mendel, but find three generations of Becquerels. It is a pleasure to note throughout the work frequent references to the work of Americans, living and dead, of whom we may mention Rowland, Newcomb, Michelson, R. W. Wood, Campbell, E. B. Wilson and W. M. Davis, whose familiar hand is recognized in the admirable drawing of meanderings in the article Fluss. This fact, which is now becoming more and more general, may partially reconcile us to the state of affairs upon which we have commented at the beginning. It may seem premature to review a work that is not yet finished, but it seems of importance to call the attention of the public to this very important and desirable work.

\section{Arthur Gordon Webster}

July 26, 1913

Studien an intracellularen Symbionten. I. Die intracellularen Symbionten der Hemipteren. By Dr. Phil. Paul Buchner, Privatdocent in the University of Munich. Reprinted from "Archiv für Protistenkunde," Vol 26. Jena, 1912. Pp. 116, 12 plates and 29 text figures.
For many years students of insect morphology and embryology have noted in the fat body of larval and adult insects and in certain eggs and embryos, peculiar corpuscle- or rodlike bodies, seemingly extraneous in origin and whose nature and function could not be satisfactorily explained.

Thus, as far back as 1850, Leydig observed the appearance, in embryos of viviparous aphids, of " a green or yellow granular mass which at first apparently lay free between the cells, but later massed in spherical form, became enclosed by a membrane, and took part in the formation of the vegetative organs of the insect." This constituted the mass later designated by Huxley and by Lubbock as the "pseudovitellus," a name very generally accepted by embryologists, though some have regarded the mass as having a very specific function. According to Babiani, who demonstrated its origin within an enlarged cell of the follicular epithelium, it represents the vestigial male sex gland of the agamic individual. On the other hand, Witlaczil regarded it in the form of the "green body" of the adult aphid, as an excretory organ, replacing the Malpighian tubes which are lacking in some species.

Of less striking appearance are the bacteroidal bodies found by Blochmann, '84, in the eggs of certain ants and, later, studied more fully by him in the eggs and adult fat body of Blatta and Periplaneta. These little bodies, which Wheeler, '89, called Blochmann's corpuscles, have also been found in the larval fat cells of Pieris and in various orthoptera. They are in the form of minute, straight or slightly bent rods, 6-8 $\mu$ long and, as Blochmann was able to determine, multiply by cross division. He was unable to cultivate them, but regarded them as symbiotic bacteria.

In recent years there has accumulated evidence to show that these scattered structures are related and that Blochmann was right in interpreting them as symbiotic forms. Many such suggestions appear in the literature of the past fifteen or twenty years, but it is especially the work of Mercier (1906), Sulc (1906 